\title{
Acute coronary syndrome and coronary microfistulae left ventricular.
}

\section{A rare event, but possible}

\author{
Francesco Messinaa, Sergio Croscab \\ a Diagnostic Radiology Unit, Hospital of Locri, Reggio Calabria, Italy \\ ${ }^{b}$ Internal Medicine Unit, Hospital of Lipari, ASP 5 Messina, Italy
}

\section{ARTICLE INFO}

Article history:

Received: 1. 7. 2017

Received in revised form: 3. 2. 2018

Accepted: 5. 2. 2018

Available online: 12. 3. 2018

\section{SOUHRN}

Koronární pištěle představují vzácnou anatomickou anomálii; incidence těchto pištělí ústících do levé komory srdeční je nízká. Hypertrofie hrotu levé komory je poměrně vzácným projevem hypertrofické kardiomyopatie, někdy je spojena s prítomností koronární píštěle. Popisujeme případ koronární mikropištěle ústící do levé komory a spojené s apikální hypertrofickou kardiomyopatií, která se poprvé projevila jako akutní koronární syndrom v podobě infarktu myokardu bez elevací úseku ST (NSTEMI).

(c) 2019, ČKS.

Klíčová slova:

Akutní koronární syndrom

Apikální hypertrofická

kardiomyopatie

Píštěle z koronární tepny do levé

komory

Keywords:

Acute coronary syndrome

Apical hypertrophic

cardiomyopathy

Coronary artery-left ventricular

fistulae

\begin{abstract}
Coronary fistulae are rare anatomic anomalies and those ones draining in left ventricle have low incidence. Apical hypertrophy of left ventricle is a relatively rare manifestation of hypertrophic cardiomyopathy, sometimes associated with coronary fistulae. We show the case of a coronary microfistulae draining on left ventricle associated with an apical hypertrophic cardiomyopathy which manifested for the first time as an acute coronary syndrome non-ST elevation myocardial infarction (NSTEMI).
\end{abstract}

\section{Introduction}

Coronary fistulae are rare anomalies characterized by a direct connection between an epicardial coronary artery and a cardiac chamber or another cardiac vessel..$^{1,2}$ The most frequent points of drainage are the right cardiac chambers, superior vena cava and pulmonary artery. ${ }^{3-5}$ Congenital forms are a prevalence of $0,1-0,2 \%$ in patients underwent to coronary angiography and between them those ones draining into the left ventricle are far and away most rare. ${ }^{6}$ Clinical manifestations are related to their origin, dimensions and drainage site. They consist in angina pectoris, heart failure, arrhythmias, syncope, acute myocardial infarction and infective endocarditis. ${ }^{6,7}$ Rarely they dramatically manifest with a rupture. ${ }^{8,9}$ Apical left ventricle hypertrophy is a relatively rare manifestation of hypertrophic cardiomyopathy, with high incidence of coronary fistulae. ${ }^{10,11}$

\section{Case presentation}

We show the case of a female patient of 70 years, who went to the Emergency Department for a constrictive chest pain. In her clinical history there are COPD, psoriasis and episodes of atrial fibrillation in treatment with new oral anticoagulant therapy. A few years prior to presentation she underwent pharmacological echo-stress for atypical chest pain resulted negative for myocardial ischemia. ${ }^{12-17} \mathrm{Her}$ arterial pressure was $120 / 80 \mathrm{mmHg}$ and her saturation $96 \%$. The ECG showed sinus rhythm 64 bpm, left ventricle hypertrophy, ST segment depression in the anterior precordial leads with negative T wave. The transthoracic echocardiogram showed an important apical hypertrophy with preserved ejection fraction. Blood test showed a marked increase of troponin $\mathrm{T}(9.2 \mathrm{pg} / \mathrm{dL})$. On the second day she underwent coronary angiography, which showed coronary vessels free from significant le- 


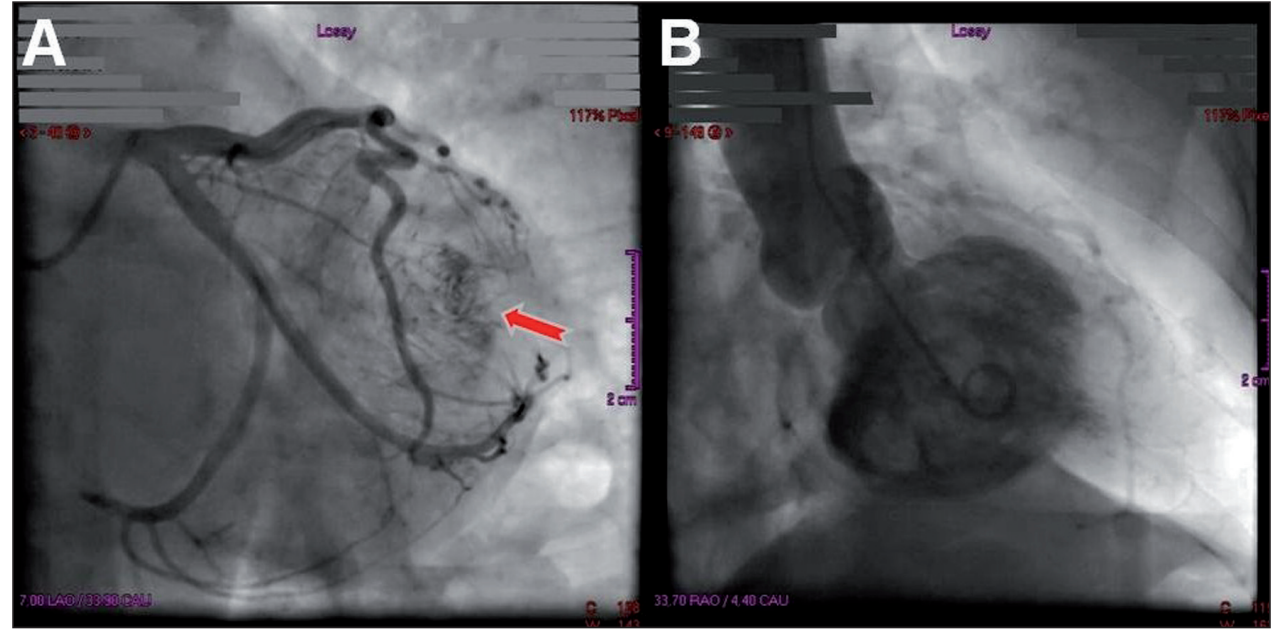

Fig. 1 - (A) Coronary angiography showing passage of contrast agent into the left ventricle during the diastolic phase (arrow), suggesting coronary microfistula. (B) Left ventriculography showing apical hypertrophy.

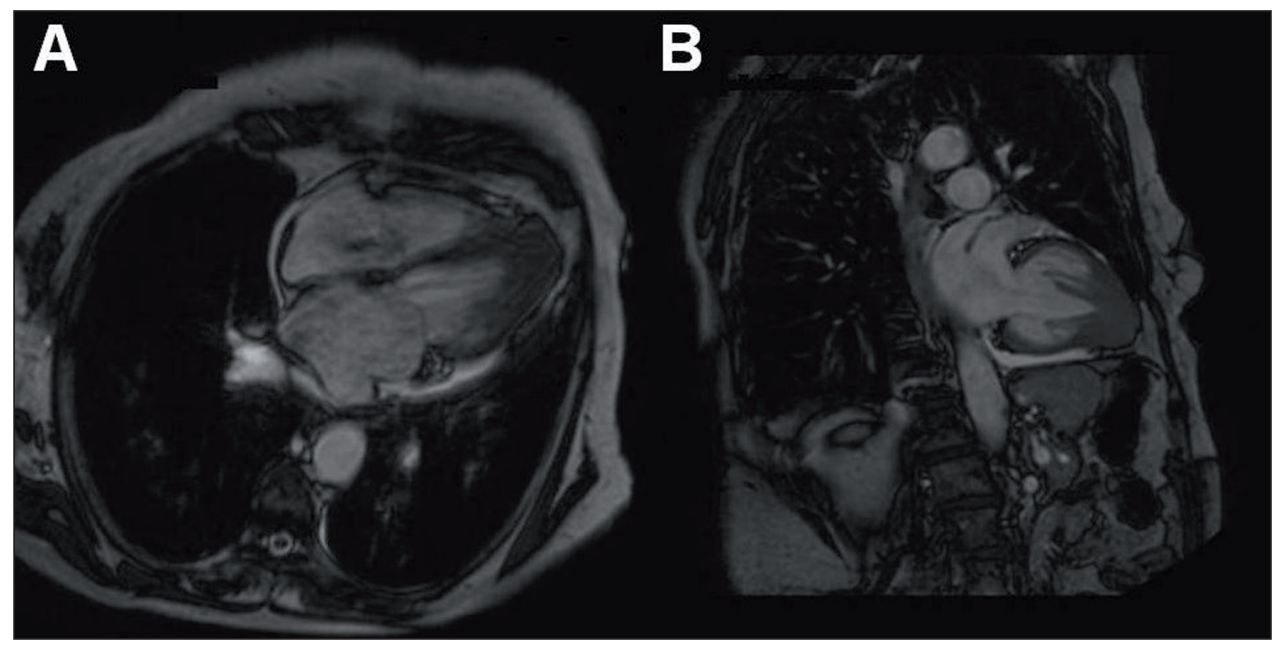

Fig. 2 - Cine (steady state free precession sequence) Cardiac Magnetic Resonance images on horizontal long-axis (A) and vertical long-axis (B) show hypertrophy of distal segments and apex of the left ventricle with small pericardial effusion.

sions with important apical hypertrophy and presence of coronary microfistulae draining in the left ventricle. (Fig. 1). CMR, performer for differential diagnosis with other forms of cardiomyopathies, allowed the diagnosis of apical hypertrophic cardiomyopathy (Fig. 2). Because of microfistulae characteristics they couldn't be treated neither by transcatheter occlusion nor surgically. ${ }^{18-20}$ Due to COPD beta blockers were avoided and an anti-ischemic therapy was initiated (clinical onset was NSTEMI) in association with Ivabradine $10 \mathrm{mg} / \mathrm{day}$. The patient remained asymptomatic for other episodes of chest pain.

\section{Discussion}

Coronary fistulae are rare anomalies and those ones draining into the left ventricle are only a minor percentage. This condition is probably due to a persistence of the embryonic coronary microcirculation. ${ }^{21-23}$ The consequence is a volume overload similar to the aortic regurgitation that generates in the old age angina pectoris in the majority of patients. Ischemia was attributed to the coronary steal phenomenon. ${ }^{3,6}$ For what concerns the coexistence of coronary microfistulae and apical hypertrophy several hypothesis were made. Microfistulae could cause left ventricle hypertrophy by a reactive mechanism through ischemia induction due to the coronary steal phoenomenon or to volume overload. Another hypothesis is the existence of a common etiological factor as a genetic mutation. Both microfistulae and apical hypertrophic cardiomyopathy can cause angina pectoris and their coexistence can aggravate the clinical manifestation. ${ }^{24-26}$ However, ischemia caused by coronary microfistulae and by apical cardiomyopathy is more often benign. Because of the rarity of this condition the natural course is not well known. To date the best therapy is based on beta blockers. In our case the coexistence of COPD didn't allow such therapy so Ivabradine was administered. Furthermore aspirin, pan- 
toprazole and a statin were added because the presentation was a NSTEMI (chest pain duration was major of $20 \mathrm{~min}$ and the concomitant presence of symptoms and ECG alterations allowed the diagnosis coherently with current NSTE-ACS guidelines). Apical hypertrophic cardiomyopathy can occasionally show typical acute coronary syndromes symptoms and electrocardiographic changes and so it should be considered as a differential diagnosis. ${ }^{27}$ The patient remained asymptomatic.

Our case strengthens the evidence of an association between coronary microfistulae and apical cardiomyopathy. Furthermore must be emphasized that a type 2 myocardial infarction could be the first manifestation in previously asymptomatic patients. A best knowledge of the etiological and pathophysiological mechanisms will allow a better management.

\section{Conflict of interest}

None.

\section{Funding body}

None.

\section{Ethical statement}

Authors state that the research was conducted according to ethical standard.

\section{Informed consent}

Informed consent was obtained from the patient.

\section{References}

1. Oncel D, Oncel G. Right coronary artery to left ventricle fistula - effective diagnosis with 64-MDCT. Int J Cardiovasc Imaging 2007;23:287-291

2. Said SA, el Gamal MI, van der Werf T. Coronary arteriovenous fistulas: collective review and management of six new cases changing etiology, presentation, and treatment strategy. Clin Cardiol 1997;20:748-752.

3. Gillebert C, Van Hoof R, Van de Werf F, et al. Coronary artery fistulas in an adult population. Eur Heart J 1986;7:437-443.

4. Pleva L, Jonszta T, Kukla P. Congenital coronary anomalies. Cor Vasa 2014;56:e27-e36.

5. Ozcan OU, Gulec S. Coronary artery ectasia. Cor Vasa 2013;55:e242-e247.

6. Uçar O, Ciçekçioglu H, Cetin M, et al. Coronary artery-left ventricular microfistulae associated with apical hypertrophic cardiomyopathy. Cardiol J 2011;18:307-309.

7. Montagna MT, Cristina ML, De Giglio O, et al. Serological and molecular identification of Legionella spp. isolated from water and surrounding air samples in Italian healthcare facilities. Environ Res 2016;146:47-50.
8. Baello P, Sevilla B, Roldán I, et al. Left to right shunt for congenital coronary arterio-venous fistulas. Rev Esp Cardiol 2000;53:1659-1662.

9. Levin DC, Fellows KE, Abrams HL. Hemodynamically significant primary anomalies of the coronary arteries. Angiographic aspects. Circulation 1978;58:25-34. Review.

10. Gregor P, Čurila K. Hypertrophic cardiomyopathy-What is new? Cor Vasa 2012;54:e300-e304.

11. Chung T, Yiannikas J, Freedman SB, et al. Unusual features of apical hypertrophic cardiomyopathy. Am J Cardiol 2010;105:879-883.

12. Imbalzano $E$, Casale $M$, D'Angelo $M$, et al. Cardiovascular risk and psoriasis: a role in clinical cardiology? Angiology 2015;66:101-103.

13. Dattilo G, Lamari A, Scarano M, et al. Coronary artery disease and psoriasis. Minerva Cardioangiol 2014;62:119-121

14. Dattilo G, Imbalzano G, Casale M, et al. Psoriasis and Cardiovascular Risk: Correlation Between Psoriasis and Cardiovascular Functional Indices. Angiology 2018;69:31-37.

15. Dattilo G, Falanga G, Casale M, et al. Oral Anticoagulants: Old and New Therapy (Book Chapter). Advances in Medicine and Biology 2015;83:13-70.

16. Dorobantu M, Vatasescu R. Oral anticoagulation during atrial fibrillation ablation: Facts and controversies. Cor Vasa 20013;55:e101-e106.

17. Dattilo G, Imbalzano E, Lamari A, et al. Ischemic heart disease and early diagnosis. Study on the predictive value of 2D strain. Int J Cardiol 2016;215:150-156.

18. Gundogdu F, Arslan S, Buyukkaya E, et al. Coronary artery fistula in a patient with coronary artery disease: evaluation by coronary angiography and multidetector computed tomography. Int J Cardiovasc Imaging 2007;23:299-302.

19. Patanè $S$, Marte $F$, Sturiale $M$ et al. Acute myocardial infarction with significant left main coronary artery stenosis, significant 3-vessel coronary artery disease and elevated troponin I at admission. Int J Cardiol 2011;153:e1-e2.

20. Gregor $\mathrm{P}$, Línková $\mathrm{H}$. Imaging methods in cardiomyopathies. Cor Vasa 20017;59:e157-e162.

21. Hutchins GM, Kessler-Hanna A, Moore GW. Development of the coronary arteries in the embryonic human heart. Circulation 1988;77:1250-1257.

22. Imbalzano E, Dattilo G, Scarpelli M, et al. Left coronary artery fistula to right ventricle complicated heart failure in a patient on hemodialysis. Intern Emerg Med 2013;8:765766.

23. Angelini P. Normal and anomalous coronary arteries: definitions and classification. Am Heart J 1989;117:418-434.

24. Alyan O, Ozeke O, Golbasi Z. Coronary artery-left ventricular fistulae associated with apical hypertrophic cardiomyopathy. Eur J Echocardiogr 2006;7:326-329.

25. Delarche N, Colle JP. Multiple left coronary-ventricular microfistula and apical hypertrophy. Arch Mal Coeur Vaiss 1993;86:75-78.

26. Penas Lado M, Pasalodos J, Pérez Alvarez L, et al. Apical hypertrophic cardiomyopathy and coronary arteriovenous fistula. Rev Esp Cardiol 1991;44:131-133.

27. Abdin A, Eitel I, de Waha S, Thiele H. Apical hypertrophic cardiomyopathy presenting as acute coronary syndrome. Eur Heart J Acute Cardiovasc Care 2016;5:289-291. 